\title{
BamHI RFLP for the GHRHR locus
}

Y.Cao, J.K.Wagner, A.Eblé, P.Hindmarsh ${ }^{1}$ and P.E.Mullis*

Unversty of Bern, Department of Paediatrics, Inselspital, $\mathrm{CH}-3010$ Bern,

Switzerland and 'Cobbold Laboratonies, The Middlesex Hospotal',

London W1N BAA, UK

Source/Description: HPR3Z is a $1.6 \mathrm{~kb}$ human growth hormone releasing hormone (GHRH) receptor cDNA clone described by Mayo (1) inserted into pGEM7Z. Sense: cut with HindIII, use SP6; antisense: cut BamHI, use T7 polymerase.

Polymorphism: BamHI identifies a two allele polymorphism with bands either at $2.6 \mathrm{~kb}$ (A1) or $2.4 \mathrm{~kb}$ (A2) and an invariant band at $8.5 \mathrm{~kb}$.

Frequency: Studied in 48 unrelated healthy Caucasians.

$\mathrm{A} 1=0.72$

$\mathrm{A} 2=0.28$

Calculated heterozygosity $=.40$.

Not Polymorphic For: EcoRI, PvuII, PstI, BglI, BglII, BclI, HindIII, HincI, MspI and FocI.

Chromosomal Localisation: Human GHRH receptor (GHRHR) has been mapped to chromosome 7p14 (2).

Mendelian Inheritance: Co-dominant inheritance of alleles A1 and A2 was observed in 29 individuals from 5 families.

Probe Availability: Probe available on request from K.E.Mayo, Department of Biochemistry, Molecular Biology, and Cell Biology, Northwestern University, Evanston, IL 60208, USA.

Acknowledgements: This work was supported by grants from Swiss National Science Foundation (32-33535.92) and Pharmacia (Switzerland). We thank K.E.Mayo for supplying the HPR3Z probe.

References: 1) Mayo,K.E. (1992) Mol. Endocrinol. 6, 1734-1744. 2) Gaylinn,B.G., von Kap-Herr,C., Golden, W.L. and Thorner,M.O. (1994) Genomics 19, 193-195.

* To whom correspondence should be addressed 